\title{
Effect of soil moisture on composition and diversity of trees in tropical dry forest
}

\begin{abstract}
The rainfall gradients and the availability of soil water are highly associated with the distribution, diversity and primary productivity of plant communities. Studies have also indicated the association of drought with increased mortality and decreased growth rates in tropical plants. Here we are presenting some results from our study in tropical dry forests of India where we have observed the influence of soil moisture content (SMC) on composition and diversity of trees in the forest region. The research was conducted in a mature, naturally established and unmanaged tropical dry forest. In our study, Shannon-Wiener index, Whittaker's index of species evenness and Margalef's index of species richness of the trees in the three growth stages (i.e., adult, saplings and seedlings) exhibited significant positive relationships with SMC. We suggest that the climate change led alterations in environmental conditions may become lethal to a large number of established species, which could immediately be replaced by the immigrants. Therefore, the species response to variations in SMC should be properly investigated while designing the reforestation programs for the tropical dry forest.
\end{abstract}

Keywords: soil moisture content, tropical dry forest, species composition, species diversity
Volume 3 Issue I - 2018

\author{
Chaturvedi RK,' Raghubanshi AS² \\ 'Center for Integrative Conservation, Xishuangbanna Tropical \\ Botanical Garden, Chinese Academy of Sciences, China \\ ${ }^{2}$ Institute of Environment and Sustainable Development, Banaras \\ Hindu University, India
}

\begin{abstract}
Correspondence: Chaturvedi RK, Centre for Integrative Conservation, Xishuangbanna Tropical Botanical Garden, Chinese Academy of Sciences, Menglun, Mengla, Yunnan 666303, China, Email ravikanthchaturvedil0@gmail.com.ravi@xtbg.ac.cn
\end{abstract}

Received: October 30, 2017 | Published: January II, 2018

\section{Introduction}

The distribution, diversity and primary productivity of plant communities have been reported to be highly associated with rainfall gradients and the availability of soil moisture. ${ }^{1-12}$ According to the theory of non-equilibrium ecology, the soil water availability is the most important factor in system dynamics. ${ }^{13}$ Along with tropical dry forests, the rainfall conditions have also been observed to influence the distribution and diversity of plants in the moist and wet tropics, ${ }^{14-17}$ therefore soil moisture availability could be one of the main factors, affecting habitat associations of tropical trees, shrubs and herbs. ${ }^{18-21}$ Studies have also indicated the association of drought with increased mortality and decreased growth rates in tropical plants. ${ }^{22-28}$ These studies have also suggested that the differences for drought resistance among species might be a major factor affecting composition and diversity of plant species in the dry tropics. Variation in SMC leads to changes in the structure and function of the forest ecosystems. These changes could favor few species to establish and also could become responsible for the removal of some species. If the changes in environmental conditions are very high, it may become lethal to a large number of established species, which could immediately be replaced by the immigrants. ${ }^{29}$ Together with low SMC, disturbance such as cattle browsing and harvesting usually leads to an immediate decline in biodiversity and the process of regeneration. ${ }^{26-28}$ Therefore, the species composition of a forest experiencing disturbance will be a cumulative outcome of differential responses of species to disturbance. Few species could tolerate the disturbance while others may disappear. Here we are presenting some important results from our study in tropical dry forests of India. The research was conducted in a mature, naturally established and unmanaged tropical dry forest $\left(24^{\circ} 18^{\prime} 07^{\prime \prime} \mathrm{N}\right.$ and $83^{\circ} 05^{\prime} 57^{\prime \prime} \mathrm{E}$ to $25^{\circ} 00^{\prime} 17^{\prime \prime} \mathrm{N}$ and $82^{\circ} 37^{\prime} 38^{\prime \prime}$ E). Results from the study showed the significance of soil depth and soil physical and chemical properties which are directly linked with soil moisture content (SMC) in influencing the plant diversity of the dry deciduous forest located in Vindhyan highlands, India. Our study reported decline in the number of species with decrising SMC. In our study, it was also observed that among the dominant or codominant tree species, Acacia catechu, Hardwickia binata, Lagerstroemia parviflora, Lannea coromandelica and Zizyphus glaberrima increased in importance value with increasing level of soil moisture stress, suggesting that their ability to tolerate drought was higher than that of the other species in the community.In our study, Shannon-Wiener index, Whittaker's index of species evenness and Margalef's index of species richness of the trees in the three growth stages (i.e., adult, saplings and seedlings) exhibited significant positive relationships with SMC (Figure 1). Among the three growth stages, the variability in SMC explained $65 \%$ (in saplings) to $77 \%$ (in adults) variability in Shannon-Wiener index, 60\% (in adults) to 68\% (in saplings) variability in Whittaker's evenness index and 39\% (in saplings) to $61 \%$ (in seedlings) variability in Margalef's richness index. Slope of relationships between soil moisture content and diversity indices had given maximum slope for seedling species as compared to adults and saplings showing greater effect of soil moisture content on the diversity of seedling species.

\section{Conclusion}

The study indicates that tropical dry forests contain considerable plant diversity which are highly influenced by soil moisture conditions. Due to the effects of climate change, the variation in SMC leads to changes in the structure and function of the forest ecosystems. These changes could favor few species to establish and also could become responsible for the removal of some species. If the changes in environmental conditions are very high, it may become lethal to a large number of established species, which could immediately be replaced by the immigrants. Therefore, the species response to variations in SMC should be properly investigated while designing the reforestation programs for the tropical dry forest. 


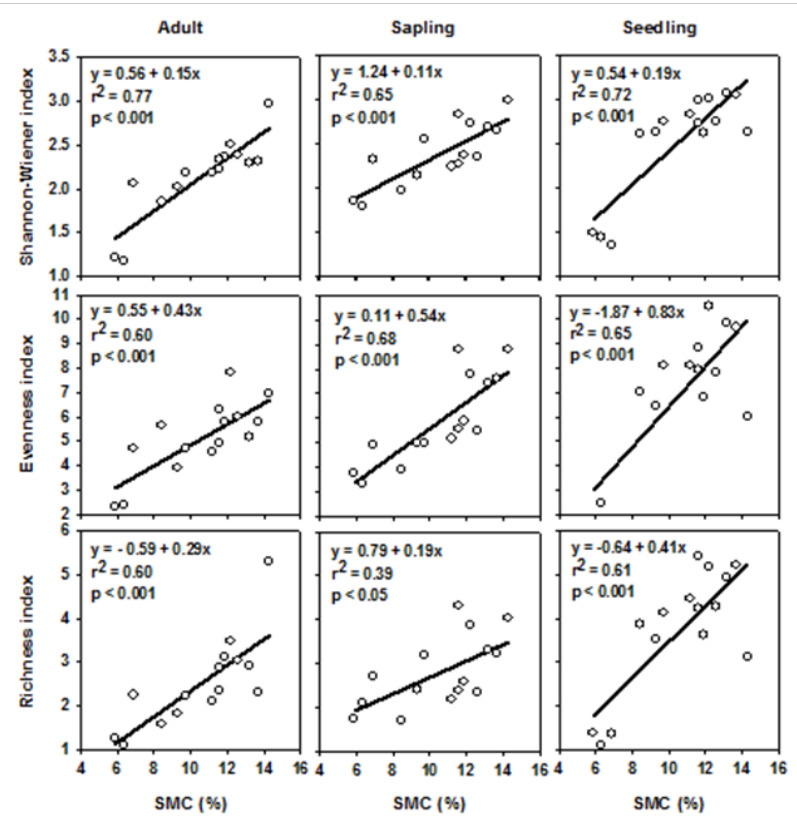

Figure I Effect of soil moisture content on Shannon-Wiener index, Whittaker evenness index and Margalef richness index of adult, sapling and seedling species in the forest of Vindhyan highlands (Source: Chaturvedi 2010).

\section{Acknowledgements}

R.K.C. thanks Council of Scientific and Industrial Research, India (award no. 09/13(452)/2012-EMR-I) and National Natural Science Foundation of China (NSFC), Chinese Academy of Science, China (grant No. 31750110466) for financial support.

\section{Conflicts of interest}

None.

\section{Funding}

None.

\section{References}

1. Lieth H. Primary production of the major vegetation units of the world. In: Lieth H, Whittaker RH, editors. Primary productivity of the biosphere. Springer, Berlin Heidelberg New York, USA; 1975. p. 203-231.

2. Boyer JS. Plant productivity and environment. Science. 1982;218(4571):443-448.

3. Currie DJ, Paquin V. Largescale biogeographical patterns of species richness of trees. Nature. 1987;329:326-327.

4. O'Brien EM. Climatic gradients in woody plant species richness:towards an explanation based on an analysis of southern Africa's woody flora. Journal of Biogeography. 1993;20(2):181-198.

5. Chaturvedi RK, Raghubanshi AS, Singh JS. Carbon density and accumulation in woody species of tropical dry forest in India. Forest Ecology and Management. 2011a;262(8):1576-1588.

6. Chaturvedi RK, Raghubanshi AS, Singh JS. Leaf attributes and tree growth in a tropical dry forest. Journal of Vegetation Science. 2011b;22(5):917-931

7. Chaturvedi RK, Raghubanshi AS, Singh JS. Plant functional traits with particular reference to dry deciduous forests: a review. Journal of Biosciences. 2011c;36(5):963-981.
8. Chaturvedi RK, Raghubanshi AS, Singh JS. Effect of small scale variations in environmental factors on the distribution of woody species in tropical deciduous forests of Vindhyan Highlands, India. Journal of Botany. 2011d. 10 p.

9. Chaturvedi RK, Raghubanshi AS, Singh JS. Growth of tree seedlings in a dry tropical forest in relation to soil moisture and leaf traits. Journal of Plant Ecology. 2013;6(2):158-170.

10. Chaturvedi RK, Raghubanshi AS, Singh JS. Relative effects of different leaf attributes on sapling growth in tropical dry forest. Journal of Plant Ecology. 2014;7(6):544-558.

11. Chaturvedi RK, Raghubanshi AS. Species Composition, Distribution and Diversity of Woody Species in tropical dry forest of India. Journal of Sustainable Forestry. 2014;33(8):729-756.

12. Gaviria J, TurnerBL, EngelbrechtBMJ. Drivers of tree species distribution across a tropical rainfall gradient. Ecosphere. 2017;8(2):e01712.

13. Xiong XG, Han XG, Zhow CP. Grazing system management based on equilibrium and non equilibrium ecology (in Chinese). Acta Prataculturae Sinica. 2005;14(6):1-6.

14. Gentry AH. Changes in plant community diversity and floristic composition on environmental and geographic gradients. Annals of the Missouri Botanical Garden. 1988;75(1):1-34.

15. Condit R. Ecological implications of changes in drought patterns:shift in forest composition in Panama. Climate Change. 1998;39(2-3):413-427.

16. Swaine MD. Rainfall and soil fertility as factors limiting forest species distributions. Journal of Ecology. 1996;84(3):419-428.

17. Bongers F, Poorter L, Van Rompaey RSAR, et al.. Distribution of twelve moist forest canopy tree species in Liberia and Cote d'Ivoire:response curves to a climatic gradient. Journal of Vegetation Science. 1999;10(3):371-382.

18. Whitmore TC. Tropical rainforests of the Far East, Oxford University Press, Oxford, $2^{\text {nd }}$ ed. USA; 1984. 352 p.

19. Richards PW. The tropical rain forest:an ecological study,. Cambridge University Press, Cambridge, 2nd ed. USA; 1998.

20. Sollins P. Factors influencing species composition in tropical lowland rainforest:Does soil matter? Ecology. 1998;79(1):23-30.

21. Webb CO, Peart DR. Habitat associations of trees and seedlings in a Bornean rain forest. Journal of Ecology. 2000;88(3):464-478.

22. Turner IM. The seedling survivorship and growth of three Shorea species in a Malaysian tropical rain forest. Journal of Tropical Ecology. 1990;6(4):469-478.

23. Fisher BL, Howe HF, Wright SJ. Survival and growth of Virola surinamensis yearlings: Water augmentation in gap and understory. Oecologia. 1991;86(2):292-297.

24. Veenendaal EM, Swaine MD, Agyeman VK, et al.. Differences in plant and soil water relations in and around a forest gap in West Africa during the dry season may influence seedling establishment and survival. Journal of Ecology. 1995;83(1):83-90.

25. Condit R, Hubbell SP, Foster RB. Mortality rates of 205 neotropical tree and shrub species and the impact of severe drought. Ecol Monographs. 1995;65(4):419-439.

26. Chaturvedi RK, Raghubanshi AS, Singh JS. Effect of grazing and harvesting on diversity, recruitment and carbon accumulation of juvenile trees in tropical dry forests. Forest Ecology and Management. 2012;284:152-162.

27. Chaturvedi RK, Raghubanshi AS, Singh JS. Sapling harvest: A predominant factor affecting future composition of tropical dry forests. Forest Ecology and Management. 2017a;384:221-235. 
28. Chaturvedi RK, Raghubanshi AS, Tomlinson KW, et al.. Impacts of human disturbance in tropical dry forests increase with soil moisture stress. Journal of Vegetation Science. 2017 b;28(5):997-1007.
29. Sheil D. Tropical forest diversity, environmental change and species augmentation: after intermediate disturbance hypothesis. Journal of Vegetation Science. 1999;10(6):851-860. 